\title{
Dokdonella koreensis gen. nov., sp. nov., isolated from soil
}

\author{
Jung-Hoon Yoon, So-Jung Kang and Tae-Kwang Oh \\ Korea Research Institute of Bioscience and Biotechnology (KRIBB), PO Box 115, Yusong, \\ Taejon, Korea
}

Correspondence

Jung-Hoon Yoon

jhyoon@kribb.re.kr

Tae-Kwang Oh

otk@kribb.re.kr
Two Gram-negative, motile, non-spore-forming and rod-shaped bacterial strains, DS-123 ${ }^{\top}$ and DS-140, were isolated from soil and their taxonomic positions were investigated by a polyphasic study. Strains DS $-123^{\top}$ and DS-140 grew optimally at $30{ }^{\circ} \mathrm{C}$ and $\mathrm{pH} 6.5$ without $\mathrm{NaCl}$. They contained $\mathrm{Q}-8$ as the predominant ubiquione and iso- $\mathrm{C}_{17: 1} \omega 9 c$, iso- $\mathrm{C}_{17: 0}$ and iso- $\mathrm{C}_{15: 0}$ as the major fatty acids. Major polar lipids detected in the two strains were diphosphatidylglycerol, phosphatidylglycerol, phosphatidylethanolamine and an amino-group-containing lipid that was ninhydrin-positive. Their DNA G +C contents were $71 \cdot 0$ mol\%. Strains DS $123^{T}$ and DS-140 exhibited no difference in their 16S rRNA gene sequences and possessed a mean DNA-DNA relatedness level of $92 \%$. Phylogenetic trees based on 16S rRNA gene sequences showed that strains DS $-123^{\top}$ and $D S-140$ formed a distinct evolutionary lineage within the Gammaproteobacteria. The $16 \mathrm{~S}$ rRNA gene sequences of strains DS-123 ${ }^{\top}$ and DS-140 exhibited similarity values of less than $94.1 \%$ to members of the Gammaproteobacteria. Strains DS-123 and DS-140 were distinguished from phylogenetically related genera by differences in some phenotypic properties. On the basis of phenotypic, phylogenetic and genetic data, it is proposed that strains DS-123 ${ }^{\top}$ (=KCTC $\left.12396^{\top}=\mathrm{DSM} 17203^{\top}\right)$ and DS-140 be classified in a novel genus and species, Dokdonella koreensis gen. nov., sp. nov.
Dokdo is an island located at the edge of the East Sea, Korea. Civilians have been restricted from entering the island for a long time, which may have resulted in stable preservation of microbial diversity. Recently, in an attempt to investigate the microbial community of Dokdo, many bacterial strains have been isolated and characterized taxonomically. In this study, we report the detailed taxonomic characterization of two bacterial strains, DS- $123^{\mathrm{T}}$ and DS-140, which were considered to belong to the class Proteobacteria.

Soil samples collected in Dokdo ( $\left.37^{\circ} 14^{\prime} 12^{\prime \prime} \mathrm{N} 131^{\circ} 52^{\prime} 07^{\prime \prime} \mathrm{E}\right)$ provided the source for isolation of bacterial strains. Strains DS- $123^{\mathrm{T}}$ and DS-140 were isolated by the standard dilution plating technique on twofold diluted nutrient agar (Difco) at $30^{\circ} \mathrm{C}$. Frateuria aurantia LMG $1558^{\mathrm{T}}$ and Fulvimonas soli LMG $19981^{\mathrm{T}}$, which were used as reference strains, were obtained from the BCCM/LMG (the Belgian Co-ordinated Collections of Microorganisms/Laboratorium voor Microbiologie, Universiteit Gent), Gent, Belgium. To investigate

Published online ahead of print on 9 September 2005 as DOI 10.1099/ijs.0.63802-0.

The GenBank/EMBL/DDBJ accession numbers for the 16S rRNA gene sequences of strains DS-123 ${ }^{\top}$ and DS-140 are AY987368 and AY987369, respectively.

A transmission electron micrograph of strain DS- $123^{\top}$ is available as supplementary material in IJSEM Online. their morphological and physiological characteristics, strains DS- $123^{\mathrm{T}}$ and DS-140 were routinely cultivated at $30{ }^{\circ} \mathrm{C}$ on trypticase soy agar (TSA; Difco) under aerobic conditions. Cell morphology was examined by light microscopy (Nikon E600) and transmission electron microscopy. Presence of flagella was determined by transmission electron microscopy using cells from exponentially growing cultures. Gram-reaction was determined by using the bioMérieux Gram Stain kit according to the manufacturer's instructions. The $\mathrm{pH}$ range for growth was determined in nutrient broth (Difco) that was adjusted to various $\mathrm{pH}$ values $(\mathrm{pH} 4 \cdot 5-$ 10.5 at intervals of $0.5 \mathrm{pH}$ units). The $\mathrm{pH}$ was adjusted prior to sterilization to various levels by the addition of $\mathrm{HCl}$ or $\mathrm{Na}_{2} \mathrm{CO}_{3}$. Growth in the absence of $\mathrm{NaCl}$ was investigated in trypticase soy broth prepared according to the formula of the Difco medium except that no $\mathrm{NaCl}$ was used. Growth at various $\mathrm{NaCl}$ concentrations $(0 \cdot 5,1 \cdot 0,2 \cdot 0,3 \cdot 0,4 \cdot 0$ and $5 \cdot 0 \%, \mathrm{w} / \mathrm{v}$ ) was investigated in trypticase soy broth (TSB; Difco). Growth at various temperatures $\left(4-45^{\circ} \mathrm{C}\right)$ was measured on TSA. Growth under anaerobic conditions was determined after incubation in an anaerobic chamber on TSA and on TSA supplemented with nitrate, both of which had been prepared anaerobically using nitrogen. Catalase and oxidase activities and hydrolysis of casein, gelatin, starch, urea, hypoxanthine, tyrosine, xanthine and Tweens 20, 40, 60 and 80 were determined as described by Cowan \& Steel (1965). Hydrolysis of aesculin and nitrate reduction 
were determined as described previously (Lanyi, 1987). Utilization of various substrates as sole carbon and energy sources was determined as described by Shirling \& Gottlieb (1966). Enzyme activity was determined by using the API ZYM system (bioMérieux). Susceptibility to antibiotics was tested on TSA plates using antibiotic discs containing the following concentrations: polymyxin B, $100 \mathrm{U}$; streptomycin, $50 \mu \mathrm{g}$; penicillin G, $20 \mathrm{U}$; chloramphenicol, $100 \mu \mathrm{g}$; ampicillin, $10 \mu \mathrm{g}$; cephalothin, $30 \mu \mathrm{g}$; gentamicin, $30 \mu \mathrm{g}$; novobiocin, $5 \mu \mathrm{g}$; tetracycline, $30 \mu \mathrm{g}$; kanamycin, $30 \mu \mathrm{g}$; lincomycin, $15 \mu \mathrm{g}$; oleandomycin, $15 \mu \mathrm{g}$; neomycin, $30 \mu \mathrm{g}$; carbenicillin,
$100 \mu \mathrm{g}$. Other physiological and biochemical tests were performed with the API 20E system (bioMérieux).

Cell biomass of strains DS- $123^{\mathrm{T}}$ and DS-140 for DNA extraction and for respiratory lipoquinone and polar lipid analyses was obtained from cultivation in TSB at $30^{\circ} \mathrm{C}$. Cell mass of Frateuria aurantia LMG $1558^{\mathrm{T}}$ and Fulvimonas soli LMG $19981^{\mathrm{T}}$ for respiratory lipoquinone analysis was obtained by cultivation in TSB at $30^{\circ} \mathrm{C}$. Chromosomal DNA was isolated and purified according to the method described previously (Yoon et al., 1996), with the exception

Table 1. Differential phenotypic characteristics of Dokdonella koreensis gen. nov., sp. nov. and five related genera

Genus: 1, Dokdonella koreensis gen. nov.; 2, Frateuria, data from Swings et al. (1980) and An et al. (2005); 3, Rhodanobacter, data from Nalin et al. (1999) and Im et al. (2004); 4, Fulvimonas, from Mergaert et al. (2002) and An et al. (2005); 5, Dyella, data from Xie \& Yokota (2005) and An et al. (2005); 6, Aquimonas, data from Saha et al. (2005). +, Positive reaction; -, negative reaction; ND, not determined; $\mathrm{W}$, weakly positive reaction; $\mathrm{V}$, variable reaction. Data in parentheses are for the type strain.

\begin{tabular}{|c|c|c|c|c|c|c|}
\hline Characteristic & 1 & 2 & 3 & 4 & 5 & 6 \\
\hline Catalase & + & + & + & + & $+{ }^{\star}$ or $\mathrm{W} \dagger$ & + \\
\hline Oxidase & + & - & + & + & $+\ddagger$ & + \\
\hline Colony colour & Yellow & Gold-yellow & Yellow & Deep yellow & Yellow & Yellowish-brown \\
\hline Motility & + & $\mathrm{V}(+)$ & $\mathrm{V}$ & + & $\mathrm{V}$ & + \\
\hline Nitrate reduction & $\mathrm{v}(+)$ & - & - & - & + & - \\
\hline Growth at $4 \%(\mathrm{w} / \mathrm{v}) \mathrm{NaCl}$ & - & $(-)$ & $\mathrm{ND}$ & $(+)$ & $-{ }^{\star}$ or $\mathrm{W} \dagger$ & - \\
\hline Growth at $\mathrm{pH} 4.5$ & - & + & ND & ND & $-*$ & - \\
\hline $\mathrm{H}_{2} \mathrm{~S}$ production & - & + & $-\varsigma$ & ND & $-*$ & - \\
\hline$\beta$-Glucosidase & - & $(-)$ & -11 & + & $\mathrm{w}^{\star}$ or $+\dagger$ & ND \\
\hline$\beta$-Galactosidase & - & $(-)$ & $\mathrm{V}$ & + & $\mathrm{V}$ & ND \\
\hline \multicolumn{7}{|l|}{ Hydrolysis of: } \\
\hline Aesculin & - & $(-)$ & +11 & + & $+\dagger$ & - \\
\hline Casein & + & $(-)$ & -11 & $(+)$ & $\mathrm{V}$ & + \\
\hline Gelatin & + & - & $-\S$ & - & $-{ }^{\star}$ & + \\
\hline Starch & - & $(-)$ & -11 & + & - & + \\
\hline \multicolumn{7}{|l|}{ Utilization of: } \\
\hline L-Arabinose & - & $(+)$ & - & - & $-\dagger$ & - \\
\hline Maltose & - & $(+)$ & $\mathrm{V}$ & + & + & - \\
\hline D-Mannose & - & $(+)$ & $\mathrm{V}$ & $\mathrm{V}(-)$ & + & - \\
\hline Sucrose & - & $(-)$ & $+\S$ & $(-)$ & $\mathrm{V}$ & ND \\
\hline Acetate & - & $(-)$ & $-\S$ & $(+)$ & $\mathrm{V}$ & - \\
\hline Citrate & - & $(-)$ & $\mathrm{V}$ & - & - & - \\
\hline D-Malate & - & $(-)$ & $\mathrm{V}$ & $\mathrm{V}(-)$ & $\mathrm{V}$ & - \\
\hline Presence of 2-hydroxy fatty acid & - & + & $-\S$ & - & - & - \\
\hline Presence of cyclo fatty acid & - & + & $+\S$ & - & - & - \\
\hline $\begin{array}{l}\text { Major fatty acids ( }>10 \% \text { of } \\
\text { total fatty acids) }\end{array}$ & $\begin{array}{c}\text { iso- } \mathrm{C}_{17: 1} \omega 9 c \\
\text { iso- } \mathrm{C}_{17: 0} \\
\text { iso- } \mathrm{C}_{15: 0}\end{array}$ & iso- $\mathrm{C}_{15: 0}$ & $\begin{array}{l}\text { iso- } \mathrm{C}_{17: 1} \omega 9 c \text {, } \\
\text { iso- } \mathrm{C}_{15: 0}, \\
{\text { iso- }-\mathrm{C}_{17: 0}} \$\end{array}$ & $\begin{array}{l}\text { iso- } \mathrm{C}_{15: 0}, \\
\text { iso- } \mathrm{C}_{17: 0} \\
\text { iso- } \mathrm{C}_{16: 0} \\
\text { iso- } \mathrm{C}_{17: 1} \omega 9 c\end{array}$ & $\begin{array}{c}\text { iso- } \mathrm{C}_{17: 1} \omega 9 c \\
\text { iso- } \mathrm{C}_{15: 0} \\
\text { iso- }_{17: 0}\end{array}$ & $\begin{array}{l}\text { iso- } \mathrm{C}_{15: 0} \\
\text { iso- } \mathrm{C}_{17: 1} \omega 9 c \\
\text { iso- }_{16: 0}\end{array}$ \\
\hline DNA G $+\mathrm{C}$ mol $\%$ & $71 \cdot 0$ & $62-64$ & $63-65$ & $71 \cdot 5-71 \cdot 99$ & $63 \cdot 4-64 \cdot 0$ & 75 \\
\hline
\end{tabular}

${ }^{*}$ Data for Dyella japonica from Xie \& Yokota (2005).

$\dagger$ Data for Dyella koreensis from An et al. (2005).

$\ddagger$ Data taken from An et al. (2005); a different result for Dyella japonica was obtained from Xie \& Yokota (2005).

$\S$ Data for Rhodanobacter fulvus from Im et al. (2004).

IIData for Rhodanobacter lindaniclasticus from Nalin et al. (1999).

SData for two strains (LMG $19981^{\mathrm{T}}$ and LMG 19982). 
that ribonuclease $\mathrm{T} 1$ was treated in combination with ribonuclease A to minimize contamination with RNA. The 16S rRNA gene was amplified by PCR using two universal primers as described previously (Yoon et al., 1998). Sequencing of the amplified 16S rRNA gene and phylogenetic analysis were performed as described by Yoon et al. (2003). Respiratory lipoquinones were extracted according to the method of Komagata \& Suzuki (1987) and analysed using reversedphase HPLC and a YMC ODS-A $(250 \times 4 \cdot 6 \mathrm{~mm})$ column. Polar lipids were extracted according to the procedures described by Minnikin et al. (1984) and identified by twodimensional TLC followed by spraying with appropriate detection reagents (Minnikin et al., 1984; Komagata \& Suzuki, 1987). For fatty acid methyl ester analysis, cell mass of strains DS- $123^{\mathrm{T}}$ and DS-140, Frateuria aurantia LMG $1558^{\mathrm{T}}$ and Fulvimonas soli LMG $19981^{\mathrm{T}}$ was harvested from agar plates after incubation for 6 days at $30^{\circ} \mathrm{C}$ on TSA. The fatty acid methyl esters were extracted and prepared according to the standard protocol of the MIDI/Hewlett Packard Microbial Identification System (Sasser, 1990). The DNA $\mathrm{G}+\mathrm{C}$ content was determined by the method of Tamaoka \& Komagata (1984) with a modification that DNA was hydrolysed and the resultant nucleotides were analysed by reversed-phase HPLC. DNA-DNA hybridization was performed fluorometrically by the method of Ezaki et al. (1989) using photobiotin-labelled DNA probes and microdilution wells. Hybridization was performed with five replications for each sample. The highest and lowest values obtained in each sample were excluded, and the means of the remaining three values were quoted as DNA-DNA relatedness values.

Morphological, cultural, physiological and biochemical characteristics of strains DS- $123^{\mathrm{T}}$ and DS-140 are given in the genus and species descriptions (see later) or are shown in Table 1, together with those of the four phylogenetically related genera Frateuria, Rhodanobacter, Fulvimonas and Dyella. Strains DS- $123^{\mathrm{T}}$ and DS- 140 were motile by means of polar peritrichous flagella (supplementary figure in IJSEM Online). Almost complete $16 \mathrm{~S}$ rRNA gene sequences of strains DS- $123^{\mathrm{T}}$ and DS-140, comprising 1494 nucleotides (approx. $96 \%$ of the Escherichia coli 16S rRNA sequence), were determined in this study. The 16S rRNA gene sequences of strains DS- $123^{\mathrm{T}}$ and DS-140 were identi$\mathrm{cal}$. In the neighbour-joining phylogenetic tree based on $16 \mathrm{~S}$ rRNA gene sequences, the two strains joined the genus Aquimonas by a bootstrap resampling value of $62 \cdot 3 \%$, and this cluster joined the clade comprising the genera Dyella, Frateuria, Fulvimonas and Rhodanobacter by a bootstrap resampling value of $98.7 \%$ (Fig. 1). The relationship between this cluster and the clade comprising the genus Xanthomonas and some other genera was supported by a bootstrap resampling value of $100 \%$ (Fig. 1). Strains DS$123^{\mathrm{T}}$ and DS-140 exhibited $16 \mathrm{~S}$ rRNA gene sequence similarity levels of $94 \cdot 1 \%$ to Aquimonas voraii and of less than $92 \cdot 2 \%$ to other species used in the phylogenetic analysis. Strains DS- $123^{\mathrm{T}}$ and DS-140 exhibited a mean level of DNA-DNA relatedness of $92 \%$, when their DNA was used individually as labelled DNA probes, indicating that the two strains are members of the same genomic species (Wayne et al., 1987).

The predominant respiratory lipoquinone detected in strains DS- $123^{\mathrm{T}}$ and DS- 140 was ubiquinone- $8(\mathrm{Q}-8)$ at a peak area ratio of approximately $92-95 \%$. In this study, Frateuria aurantia LMG $1558^{\mathrm{T}}$ and Fulvimonas soli LMG $19981^{\mathrm{T}}$ were analysed to contain Q-8 as the predominant ubiquinone at peak area ratios of 93 and $97 \%$, respectively. Strains DS$123^{\mathrm{T}}$ and DS-140 had cellular fatty acid profiles that contained large amounts of branched, straight-chain and hydroxy fatty acids; the major fatty acids ( $>10 \%$ of total fatty acids) were iso- $\mathrm{C}_{17: 1} \omega 9 c$, iso- $\mathrm{C}_{17: 0}$ and iso- $\mathrm{C}_{15: 0}$ (Table 2). Major polar lipids detected in strains DS- $123^{\mathrm{T}}$ and DS-140 were diphosphatidylglycerol, phosphatidylglycerol, phosphatidylethanolamine and an amino-groupcontaining lipid that was ninhydrin-positive. The DNA $\mathrm{G}+\mathrm{C}$ contents of strains DS- $123^{\mathrm{T}}$ and DS-140 were $71 \cdot 0 \mathrm{~mol} \%$.

The phylogenetic analyses based on 16S rRNA gene sequences indicated that strains DS- $123^{\mathrm{T}}$ and DS- 140 did not fall within the radiation encompassed by a recognized genus but form a distinct lineage within the

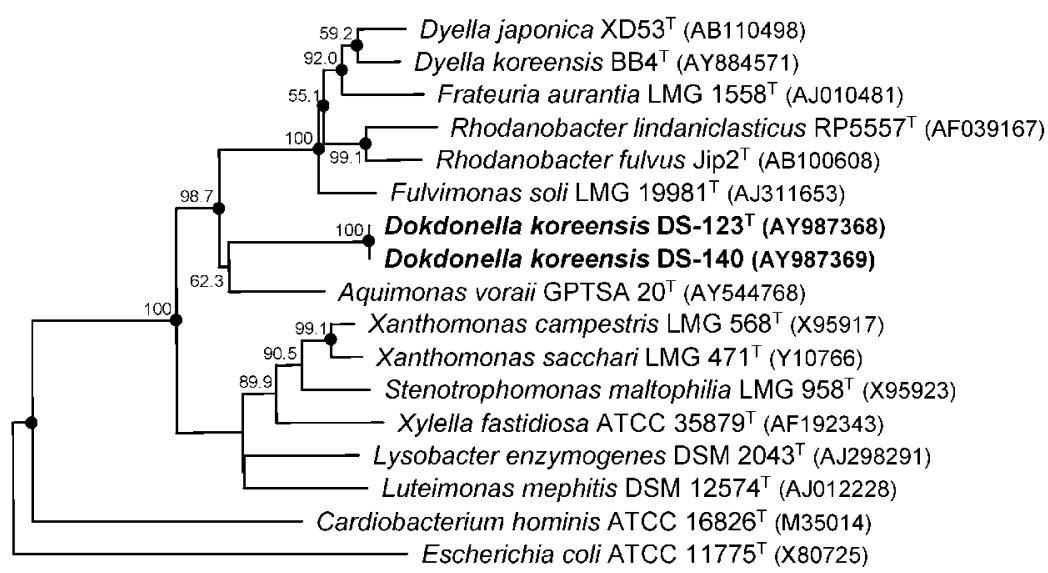

$\underline{0.01}$
Fig. 1. Neighbour-joining tree based on 16S rRNA gene sequences showing the phylogenetic positions of strains $\mathrm{DS}-123^{\top}$ and DS-140 and representatives of some other related taxa. Bootstrap values (expressed as percentages of 1000 replications) greater than $50 \%$ are shown at the branch points. Escherichia coli ATCC $11775^{\top}$ was used as an outgroup. Dots indicate that the corresponding nodes are also recovered in the trees generated with the maximum-likelihood and maximum-parsimony algorithms. Scale bar, 0.01 substitutions per nucleotide position. 
Table 2. Cellular fatty acid content (\%) of Dokdonella koreensis gen. nov., sp. nov. and five related genera

Strain: 1, Dokdonella koreensis DS-123 ${ }^{\mathrm{T}}$; 2, Dokdonella koreensis DS-140; 3, Frateuria aurantia LMG $1558^{\mathrm{T}}$, data from this study; 4 , Rhodanobacter fulvus $\mathrm{Jip} 2^{\mathrm{T}}$, data from Im et al. (2004); 5, Fulvimonas soli LMG $19981^{\mathrm{T}}$, from this study; 6, Dyella japonica XD53 ${ }^{\mathrm{T}}$, data from Xie \& Yokota (2005); 7, Dyella koreensis BB4 ${ }^{\mathrm{T}}$, data from An et al. (2005); 8, Aquimonas voraii GPTSA $20^{\mathrm{T}}$, data from Saha et al. (2005). - , Not detected or not described. Fatty acids that represented $<1 \cdot 0 \%$ in all strains were omitted.

\begin{tabular}{|c|c|c|c|c|c|c|c|c|}
\hline Fatty acid & 1 & 2 & 3 & 4 & 5 & 6 & 7 & 8 \\
\hline \multicolumn{9}{|l|}{ Straight-chain fatty acid } \\
\hline $\mathrm{C}_{14: 0}$ & $0 \cdot 4$ & $0 \cdot 3$ & $3 \cdot 2$ & - & $0 \cdot 1$ & $<0 \cdot 5$ & - & $1 \cdot 1$ \\
\hline $\mathrm{C}_{16: 0}$ & $4 \cdot 6$ & $4 \cdot 0$ & $2 \cdot 7$ & $6 \cdot 3$ & $0 \cdot 51$ & $1 \cdot 5$ & $3 \cdot 2-6 \cdot 4$ & $4 \cdot 5$ \\
\hline $\mathrm{C}_{18: 0}$ & $0 \cdot 3$ & - & $0 \cdot 3$ & - & - & $<0 \cdot 5$ & $1 \cdot 1-1 \cdot 5$ & - \\
\hline \multicolumn{9}{|l|}{ Branched fatty acid } \\
\hline iso- $\mathrm{C}_{11: 0}$ & $4 \cdot 7$ & $6 \cdot 2$ & $0 \cdot 1$ & $3 \cdot 5$ & $5 \cdot 5$ & $3 \cdot 8$ & $4 \cdot 3-10 \cdot 4$ & $7 \cdot 4$ \\
\hline iso- $\mathrm{C}_{13: 0}$ & $0 \cdot 1$ & - & $1 \cdot 2$ & - & $0 \cdot 1$ & $<0 \cdot 5$ & - or $<0.5$ & $<1 \cdot 0$ \\
\hline iso- $\mathrm{C}_{14: 0}$ & - & - & - & - & $0 \cdot 8$ & $<0.5$ & - or $<0.5$ & $1 \cdot 4$ \\
\hline iso- $\mathrm{C}_{15: 0}$ & $10 \cdot 1$ & $11 \cdot 8$ & $60 \cdot 4$ & $21 \cdot 3$ & $24 \cdot 4$ & $23 \cdot 6$ & $18 \cdot 2-22 \cdot 6$ & $25 \cdot 0$ \\
\hline iso- $\mathrm{C}_{15: 1}$ & $0 \cdot 3$ & $0 \cdot 3$ & - & $1 \cdot 2$ & $0 \cdot 2$ & - & - or $<0.5$ & $2 \cdot 3$ \\
\hline anteiso- $\mathrm{C}_{15: 0}$ & $3 \cdot 7$ & $3 \cdot 6$ & - & $6 \cdot 7$ & $3 \cdot 0$ & $1 \cdot 6$ & $0 \cdot 9-1 \cdot 0$ & $<1 \cdot 0$ \\
\hline iso- $\mathrm{C}_{16: 0}$ & $6 \cdot 2$ & $3 \cdot 8$ & - & $2 \cdot 2$ & $14 \cdot 3$ & $4 \cdot 9$ & $2 \cdot 1-2 \cdot 8$ & $17 \cdot 7$ \\
\hline iso- $\mathrm{C}_{17: 0}$ & $19 \cdot 8$ & $17 \cdot 8$ & $1 \cdot 8$ & $10 \cdot 9$ & $16 \cdot 8$ & $20 \cdot 0$ & $15 \cdot 6-26 \cdot 0$ & $2 \cdot 8$ \\
\hline anteiso- $\mathrm{C}_{17: 0}$ & $7 \cdot 7$ & $5 \cdot 9$ & - & - & $0 \cdot 8$ & $0 \cdot 7$ & - & - \\
\hline iso- $\mathrm{C}_{17: 1} \omega 9 c$ & $31 \cdot 2$ & $32 \cdot 9$ & $0 \cdot 7$ & $24 \cdot 6$ & $13 \cdot 2$ & $25 \cdot 6$ & $21 \cdot 3-28 \cdot 1$ & $19 \cdot 3$ \\
\hline iso- $\mathrm{C}_{19: 0}$ & - & - & - & - & - & $0 \cdot 7$ & $1 \cdot 6-1 \cdot 8$ & - \\
\hline \multicolumn{9}{|l|}{ Unsaturated fatty acid } \\
\hline $\mathrm{C}_{17: 1} \omega 6 c$ & $0 \cdot 4$ & $0 \cdot 4$ & - & - & $2 \cdot 0$ & - & - & - \\
\hline \multicolumn{9}{|l|}{ Hydroxy fatty acid } \\
\hline $\mathrm{C}_{12: 0} 2-\mathrm{OH}$ & - & - & $2 \cdot 3$ & - & - & - & - & - \\
\hline $\mathrm{C}_{12: 0} 3-\mathrm{OH}$ & - & - & $4 \cdot 7$ & - & - & - & - & - \\
\hline iso- $\mathrm{C}_{11: 0} 3-\mathrm{OH}$ & $6 \cdot 8$ & $9 \cdot 6$ & - & $4 \cdot 4$ & $6 \cdot 5$ & $3 \cdot 7$ & $3 \cdot 4-9 \cdot 9$ & $9 \cdot 3$ \\
\hline iso- $\mathrm{C}_{12: 0} 3-\mathrm{OH}$ & $0 \cdot 1$ & - & - & - & $1 \cdot 0$ & $<0 \cdot 5$ & - & - \\
\hline iso- $\mathrm{C}_{13: 0} 3-\mathrm{OH}$ & - & - & $1 \cdot 7$ & $3 \cdot 0$ & $3 \cdot 8$ & $3 \cdot 9$ & $2 \cdot 3-7 \cdot 1$ & - \\
\hline iso- $\mathrm{C}_{17: 0} 3-\mathrm{OH}$ & - & - & - & - & $0 \cdot 7$ & $1 \cdot 1$ & $0 \cdot 8-1 \cdot 1$ & - \\
\hline Cyclo $\mathrm{C}_{17: 0}$ & - & - & $8 \cdot 7$ & $2 \cdot 0$ & - & - & - & \\
\hline \multicolumn{9}{|l|}{ Summed feature ${ }^{\star}$} \\
\hline 1 & - & - & $1 \cdot 5$ & - & $0 \cdot 2$ & - & - or $<0.5$ & - \\
\hline 3 & $1 \cdot 0$ & $0 \cdot 9$ & $4 \cdot 5$ & $5 \cdot 9$ & $1 \cdot 8$ & $4 \cdot 0$ & $4 \cdot 9-7 \cdot 0$ & $4 \cdot 2$ \\
\hline Unknown fatty acid (ECL 11.799) & $0 \cdot 8$ & $1 \cdot 2$ & $0 \cdot 8$ & $2 \cdot 2 \dagger$ & $2 \cdot 9$ & $1 \cdot 9$ & $1 \cdot 4-4 \cdot 4 \dagger$ & - \\
\hline
\end{tabular}

*Summed feature represents groups of two or three fatty acids which could not be separated by GLC with the MIDI system. Summed feature 1 contained $\mathrm{C}_{13: 0} 3-\mathrm{OH}$ and/or iso- $\mathrm{C}_{15: 1}$. Summed feature 3 contained $\mathrm{C}_{16: 1} \omega 7 \mathrm{c}$ and/or iso- $\mathrm{C}_{15: 0} 2-\mathrm{OH}$.

†Unknown fatty acid (ECL 11.798).

Gammaproteobacteria. The predominant ubiquinone type (Q-8) of strains DS- $123^{\mathrm{T}}$ and DS-140 was the same as those of some phylogenetically related genera, Frateuria, Fulvimonas and Dyella, and Rhodanobacter fulvus, from the data compiled by Swings et al. (1980), Im et al. (2004), Xie \& Yokota (2005) and An et al. (2005) and those generated in this study. However, strains DS- $123^{\mathrm{T}}$ and DS-140 were differentiated from phylogenetically related genera by differences in some phenotypic characteristics, including DNA $\mathrm{G}+\mathrm{C}$ contents, fatty acid profiles and others (Tables 1 and 2). The DNA G $+C$ contents of strains DS- $123^{\mathrm{T}}$ and DS- 140 were higher than those of the genera Frateuria, Rhodanobacter and Dyella (Table 1). The fatty acid profiles, particularly proportions of the major fatty acid(s), distinguish strains DS- $123^{\mathrm{T}}$ and DS-140 from phylogenetically related genera Frateuria, Fulvimonas, Dyella and Aquimonas and Rhodanobacter fulvus (Table 2). In particular, the genus Frateuria was clearly differentiated from the genera Fulvimonas and Dyella as well as from strains DS-123 ${ }^{\mathrm{T}}$ and DS-140 by the proportion of iso- $\mathrm{C}_{15: 0}$ and the presence of hydroxy (2- and 3-) $\mathrm{C}_{12: 0}$ and cyclo $\mathrm{C}_{17: 0}$ (Table 2). Unfortunately, the ubiquinone type and fatty acid profile of the type species of the genus Rhodanobacter, Rhodanobacter lindaniclasticus, were not reported previously and could not be analysed in this study. It was confirmed by the original author and LMG that $R$. lindaniclasticus is not extant 
because the culture they held was contaminated and the original author's backup culture was lost. Therefore, on the basis of the phenotypic, phylogenetic and genetic data, strains DS- $123^{\mathrm{T}}$ and DS- 140 should be classified in a novel genus and species, for which the name Dokdonella koreensis gen. nov., sp. nov. is proposed.

\section{Description of Dokdonella gen. nov.}

Dokdonella (Dok.do.nel'la. N.L. fem. dim. n. Dokdonella of Dokdo, an island located on the East Sea in Korea, from where the organisms were isolated).

Cells are Gram-negative, non-spore-forming and rod-shaped. Strictly aerobic. Motile by means of polar peritrichous flagella. Catalase- and oxidase-positive. Urease-negative. The predominant ubiquinone is Q-8. The major fatty acids are iso$\mathrm{C}_{17: 1} \omega 9 \mathrm{c}$, iso- $\mathrm{C}_{17: 0}$ and iso- $\mathrm{C}_{15: 0}$. Major polar lipids are diphosphatidylglycerol, phosphatidylglycerol, phosphatidylethanolamine and an amino-group-containing lipid that is ninhydrin-positive. The DNA G $+\mathrm{C}$ content is $71.0 \mathrm{~mol} \%$. The type species is Dokdonella koreensis.

\section{Description of Dokdonella koreensis sp. nov.}

Dokdonella koreensis (ko.re.en'sis. N.L. fem. adj. koreensis pertaining to Korea, where Dokdo is located).

Exhibits the following properties in addition to those given in the genus description. Cells are Gram-negative, strictly aerobic rods, $0 \cdot 3-0 \cdot 5 \times 1 \cdot 0-2 \cdot 0 \mu \mathrm{m}$. Colonies on TSA are circular, convex, glistening, smooth, moderate yellow in colour and $1 \cdot 0-2 \cdot 0 \mathrm{~mm}$ in diameter after incubation for 6 days at $30^{\circ} \mathrm{C}$. Growth occurs at 10 and $39^{\circ} \mathrm{C}$ with an optimum temperature of $30^{\circ} \mathrm{C}$; growth does not occur at 4 and $40^{\circ} \mathrm{C}$. Optimal growth occurs without $\mathrm{NaCl}$; growth does not occur in the presence of $>3 \%(\mathrm{w} / \mathrm{v}) \mathrm{NaCl}$. Optimal $\mathrm{pH}$ for growth is 6.5 ; good growth occurs at $\mathrm{pH} 6 \cdot 5-7 \cdot 5$. Growth is observed at $\mathrm{pH} 5 \cdot 0$ and $9 \cdot 0$, but not at $\mathrm{pH} 4 \cdot 5$ and $9 \cdot 5$. Urease-negative. Tyrosine and Tweens 20, 40, 60 and 80 are hydrolysed. Hypoxanthine and xanthine are not hydrolysed. Indole is not produced. Arginine dihydrolase, lysine decarboxylase, ornithine decarboxylase and tryptophan deaminase are absent. In assays with the API ZYM system, alkaline phosphatase, esterase (C4), esterase lipase (C8), acid phosphatase and naphthol-AS-BIphosphohydrolase are present, but lipase (C14), leucine arylamidase, valine arylamidase, cystine arylamidase, trypsin, $\alpha$-chymotrypsin, $\alpha$-galactosidase, $\beta$-glucuronidase, $\alpha$ glucosidase, $N$-acetyl- $\beta$-glucosaminidase, $\alpha$-mannosidase and $\alpha$-fucosidase are absent. Susceptible to polymyxin B, chloramphenicol, gentamicin and tetracycline, but not to streptomycin, penicillin G, ampicillin, cephalothin, novobiocin, kanamycin, lincomycin, oleandomycin, neomycin or carbenicillin. Pyruvate is utilized for growth, but D-glucose, D-fructose, D-galactose, D-cellobiose, D-trehalose, D-xylose, succinate, benzoate, formate, L-glutamate and salicin are not utilized. The predominant ubiquinone is Q-8. The major fatty acids are iso- $\mathrm{C}_{17: 1} \omega 9 c$, iso- $\mathrm{C}_{17: 0}$ and iso- $\mathrm{C}_{15: 0}$. Major polar lipids are diphosphatidylglycerol, phosphatidylglycerol, phosphatidylethanolamine and an amino-groupcontaining lipid that is ninhydrin-positive. The DNA G +C content is $71 \cdot 0 \mathrm{~mol} \%$. Other phenotypic characteristics are given in Table 1.

The type strain, DS- $123^{\mathrm{T}}\left(=\mathrm{KCTC} 12396^{\mathrm{T}}=\mathrm{DSM} 17203^{\mathrm{T}}\right)$, was isolated from soil. The reference strain is DS-140.

\section{Acknowledgements}

This work was supported by the 21C Frontier program of Microbial Genomics and Applications (grant MG05-0401-2-0) from the Ministry of Science and Technology (MOST) of the Republic of Korea. We are grateful to the Ulleung County Administration and the Cultural Heritage Administration of the Republic of Korea for aiding access to Dokdo.

\section{References}

An, D.-S., Im, W.-T., Yang, H.-C., Yang, D.-C. \& Lee, S.-T. (2005). Dyella koreensis sp. nov., a $\beta$-glucosidase-producing bacterium. Int J Syst Evol Microbiol 55, 1625-1628.

Cowan, S. T. \& Steel, K. J. (1965). Manual for the Identification of Medical Bacteria. London: Cambridge University Press.

Ezaki, T., Hashimoto, Y. \& Yabuuchi, E. (1989). Fluorometric deoxyribonucleic acid-deoxyribonucleic acid hybridization in microdilution wells as an alternative to membrane filter hybridization in which radioisotopes are used to determine genetic relatedness among bacterial strains. Int J Syst Bacteriol 39, 224-229.

Im, W.-T., Lee, S. T. \& Yokota, A. (2004). Rhodanobacter fulvus sp. nov., a $\beta$-galactosidase-producing gammaproteobacterium. J Gen Appl Microbiol 50, 143-147.

Komagata, K. \& Suzuki, K. (1987). Lipids and cell-wall analysis in bacterial systematics. Methods Microbiol 19, 161-203.

Lanyi, B. (1987). Classical and rapid identification methods for medically important bacteria. Methods Microbiol 19, 1-67.

Mergaert, J., Cnockaert, M. C. \& Swings, J. (2002). Fulvimonas soli gen. nov., sp. nov., a $\gamma$-proteobacterium isolated from soil after enrichment on acetylated starch plastic. Int J Syst Evol Microbiol 52, 1285-1289.

Minnikin, D. E., O’Donnell, A. G., Goodfellow, M., Alderson, G., Athalye, M., Schaal, A. \& Parlett, J. H. (1984). An integrated procedure for the extraction of bacterial isoprenoid quinones and polar lipids. J Microbiol Methods 2, 233-241.

Nalin, R., Simonet, P., Vogel, T. M. \& Normand, P. (1999). Rhodanobacter lindaniclasticus gen. nov., sp. nov., a lindane-degrading bacterium. Int J Syst Bacteriol 49, 19-23.

Saha, P., Krishnamurthi, S., Mayilraj, S., Prasad, G. S., Bora, T. C. \& Chakrabarti, T. (2005). Aquimonas voraii gen. nov., sp. nov., a novel gammaproteobacterium isolated from a warm spring of Assam, India. Int J Syst Evol Microbiol 55, 1491-1495.

Sasser, M. (1990). Identification of Bacteria by Gas Chromatography of Cellular Fatty Acids. Newark, DE: MIDI.

Shirling, E. B. \& Gottlieb, D. (1966). Methods for characterization of Streptomyces species. Int J Syst Bacteriol 16, 313-340.

Swings, J., Kersters, G. K., De Vos, P., Gosselé, F. \& De Ley, J. (1980). Frateuria, a new genus for "Acetobacter aurantius". Int J Syst Bacteriol 30, 547-556. 
Tamaoka, J. \& Komagata, K. (1984). Determination of DNA base composition by reverse-phase high-performance liquid chromatography. FEMS Microbiol Lett 25, 125-128.

Wayne, L. G., Brenner, D. J., Colwell, R. R. \& 9 other authors (1987). International Committee on Systematic Bacteriology. Report of the ad hoc committee on reconciliation of approaches to bacterial systematics. Int J Syst Bacteriol 37, 463-464.

Xie, C.-H. \& Yokota, A. (2005). Dyella japonica gen. nov., sp. nov., a $\gamma$-proteobacterium isolated from soil. Int J Syst Evol Microbiol 55, $753-756$.
Yoon, J.-H., Kim, H., Kim, S.-B., Kim, H.-J., Kim, W. Y., Lee, S. T., Goodfellow, M. \& Park, Y.-H. (1996). Identification of Saccharomonospora strains by the use of genomic DNA fragments and rRNA gene probes. Int J Syst Bacteriol 46, 502-505.

Yoon, J.-H., Lee, S. T. \& Park, Y.-H. (1998). Inter- and intraspecific phylogenetic analysis of the genus Nocardioides and related taxa based on 16S rRNA gene sequences. Int J Syst Bacteriol 48, 187-194.

Yoon, J.-H., Kang, K. H. \& Park, Y.-H. (2003). Psychrobacter jeotgali sp. nov., isolated from jeotgal, a traditional Korean fermented seafood. Int J Syst Evol Microbiol 53, 449-454. 